Svetlana Sokolov Mladenović ${ }^{1}$

University of Nis, Faculty of Economics

Đorđe Ćuzović ${ }^{2}$

Business School, Novi Sad
SCIENTIFIC REVIEW ARTICLE doi:10.5937/ekonomika1504035S

Received: October 23, 2015

Accepted: November 16, 2015

\title{
PARTNERSHIP OF TRADE AND MANUFACTURERS IN THE DEVELOPMENT OF TRADEMARKS ${ }^{3}$
}

\begin{abstract}
Trademarks are increasingly gaining in importance in modern business conditions, as evidenced by an increased market share of products with the trademark in some countries. Development of trademarks requires cooperation between manufacturers and trade. The research subject of this paper focuses on trademarks, as a result of a partnership between trade and manufacturers. The starting hypothesis in this paper is that the development of a trademark has its advantages both for manufacturers and for the trade. This hypothesis will be tested on the basis of available theoretical and empirical data on the development of trademarks, through a partnership between trade and manufacturers.
\end{abstract}

Key words: trade, manufacturers, partnership, trademark

JEL classification: M21, M31

\section{ПАРТНЕРСТВО ТРГОВИНЕ И ПРОИЗВОЪАЧА У ФУНКЦИЈИ РАЗВОЈА ТРГОВИНСКЕ МАРКЕ}

\begin{abstract}
Абстракт
У савременим условима пословања трговинска марка све више добија на значају, што потврђују и подаџи о повећању тржишног учешћа производа са трговинском марком у појединим земљама. Развој трговинске марке подразумева сарадњу између произвођача и трговине. Предмет истраживања овог рада јесте креирање трговинске марке као резултат партнерства између трговине и произвођача. Полазна претпоставка у раду је да развој трговинске марке има својих предности и за произвођаче и за трговину. Ова претпоставка биће тестирана на бази расположивих теоријско-емпиријских података о развоју трговинске марке кроз партнерски однос трговине и произвођача.
\end{abstract}

Кључне речи: трговина, произвођачи, партнерство, трговинска марка

\footnotetext{
${ }^{1}$ svetlana.sokolov@eknfak.ni.ac.rs

2 cuzovic@gmail.com

3 The paper is part of the research within the Project No. 179081, funded by the Ministry of Education, Science and Technological Development of the Republic of Serbia
} 


\section{Introduction}

Numerous changes in the environment in the early 1980s caused the development of the trade market. These are the changes which the scientific and professional community sees as "technological revolution", "information revolution", "structural revolution", and "demographic and social revolution". All these changes have had a strong impact on market conditions and the position of trading companies in the marketing macrosystem. Thus, trading companies try to develop an optimal combination of marketing instruments. Trademark, or private brand, as an instrument of trade marketing, is gaining in importance in recent years. At the same time, trademark has become the area of establishment of partnership relations between trade and manufacturers, which is the subject of this paper. The paper will first analyze the development of partnership relations between trade and manufacturers, and then trademark as a marketing instrument and partnership area. In this regard, the paper will point to the creation and functions of the trademark. The starting hypothesis of this work is that trademark development brings benefits to both manufacturers and consumers. This hypothesis will be tested through the theoretical aspect of a trademark, as well as through the analysis of case studies of METRO Cash \& Carry, which develops partnerships with manufacturers in the development of trademarks.

\section{The development of partnership relations between trade and manufacturers}

One of the motives for the formation of business partnerships between trade and manufacturers, as members of the distribution channels, is the achievement of objectives in a more efficient manner. Partnership is, in terms of its characteristics, clearly different from simple cooperation, and is defined by a highly closed relationship between trade and manufacturers. The closed nature of the relationship is reflected in a high level of cooperation, which manifests itself in the willingness of partners to help each other, the flexibility to react to changing needs and demands of consumers, or simply work together in creating a competitive position on the market. In this regard, partnership can be understood as a relationship which is characterized by a high degree of cooperation and motivation to achieve common goals (Mohr \& Spekman, 1996, p. 34).

The partnership is especially important as a way of gaining and maintaining competitive advantage. The practice of developed market economies shows numerous examples of partnerships between large trading companies and manufacturers, and it has a positive impact on lowering costs in the entire distribution system. Most often, this is achieved by: reducing the amount of inventories used by all channel members; using information technology to automatically collect, analyze, and distribute information; redistribution of redundant tasks between partners (for example, labeling of goods by the dealer); eliminating redundant procedures; inventory management based on just-intime principle; using the system for electronic data interchange (EDI) (Diamond, 2010, p. 388).

Partnership occurs through broad social, economic, and technological ties over time, as well as through mutual commitment, trust, shared goals, and communication. By establishing a partnership, both sides gain sufficient benefit. Depending on whether partnerships are established for a shorter or longer period of time, there are strategic and operational partnerships. 
Strategic partnership is a long-term business relationship between the companies, aimed at the achievement of strategic objectives and improving the competitive position of the partners, through the development of new technology, new products, and new markets. Successful strategic partnership implies the existence of a solid relationship between the partners and a long-term orientation to current results (operating efficiency and effectiveness) and future results (competitive advantage). As part of this arrangement, the partners see each other as "extension" of their own company (Ćuzović \& Sokolov Mladenović, 2013).

Operational partnership is a short-term business arrangement, focused on the implementation of operational efficiency and effectiveness. Efficiency is the ability to minimize the resources to achieve short-term goals, while effectiveness is the ability to deliver products and services in a way that is acceptable to end users. Efficiency is measured by just-in-time delivery, product quality, number of short-term orders and inventory level, and effectiveness is measured by the quality of services (Meintzer, Min \& Zacharia, 2000).

Operational decisions relate to a shorter period of time, lower level of resources, and are easier to implement and change in relation to strategic decisions. In contrast to strategic partnerships, in operational partnerships, partners cannot see each other as an "extension" of their own company.

Strategic and operational partnerships are, based on all of these characteristics, clearly distinguished from simple transactional relationships between trade and manufacturers, which rest on purchase and sales relationships.

\section{Marketing partnership of trade and manufacturers in the creation of trademarks}

A very important business segment of trading companies is the creation of product brands, or branding. Within their range, trade companies mostly have products with the manufacturer brands, but there is also the increased tendency to offer products with the trademark. Motivation for trademarks is based on the fact that this leads to larger difference in price, increases the negotiating power of trade in relation to manufacturers, and provides greater value to consumers, and, thus, loyalty of consumers to trade. Simultaneous participation of manufacturers and trade in creating value for customers is realized if the product brand is created through their coordination.

\section{Trademark as an instrument of trade marketing}

In modern business conditions, when trading companies are becoming increasingly powerful on the market, trade creates product brands, i.e. trademarks. Trademark (private label, own label, dealer brand, store brand) is the name designed by a particular trading company, a name that is profitable for a trading company, leading to customer loyalty (Kotler, Keller \& Martinović, 2014, p. 550).

In developing their own brands, i.e. product brands, trading companies can focus on one or more categories of brands. Thus, theory and practice point to four categories of trademarks (Levy \& Weitz, 2009, p. 386): premium, generic, copycat, and exclusive co-brand. 
Premium brand is a form of trademark, which can, in terms of quality and costsavings, be compared to famous product brands or trademarks. Examples of premium trademarks are: Wal-Mart's Sam's Choice, Tesco Finest, Marks \& Spencer St. Michael, Woolworth Select, etc.

Generic brand targets price-sensitive consumers, and refers to the basic products that are offered at discount prices. An example of this is the offer of milk or eggs in supermarkets, or underwear in discount chains.

Copycat brand resembles a trademark in terms of appearance and packaging, and generally refers to products of lower quality and lower prices. Copycat brand products are most often found in variety stores.

The exclusive co-brand is a trademark developed by the manufacturer, often in cooperation with trading company, which has exclusive rights to its sale. The simplest form of co-branding is when a manufacturer introduces different models and different characteristics of a product that is sold by various trading companies. Thus, for example, an exclusive co-brand product can in different forms be found in different trading companies. Much more sophisticated form of exclusive co-brand is when a manufacturer develops exclusive product or category for trading company.

In addition to the above-mentioned brands or trademark categories, trading company can focus on the following branding strategies (Zentes, Morschett \& SchrammKlein, 2007, p. 125):

1. "Umbrella brand" strategy - where all retail stores of one company have the same brand, in many cases differentiated by sub-brands;

2. "Familial brand" strategy - where a group of retail stores of a trading company has a variety of brands,

3. Combined strategy - which, for a certain group of retail stores, uses the "umbrella brand" strategy, and, for another, the "familiar brand" strategy.

These strategies, seen through the example of well-known international trading companies, may be seen in Overview 1.

Overview 1: Brand strategies, based on the example of different trading companies

\begin{tabular}{|l|l|l|}
\hline Brand strategy & Trading company & Trademark (brand) \\
\hline \multirow{4}{*}{ "Umbrella" brand } & Tesco & Tesco Extra, Tesco (Superstore), Tesco Express, Tesco Extra \\
\cline { 2 - 3 } & Edeka & Edeka aktiv markt, Edeka neukauf, Edeka center \\
\cline { 2 - 3 } & Systeme U & Marche U, Super U, Hyper U \\
\hline \multirow{5}{*}{ "Fambined strategy } & Coop & $\begin{array}{l}\text { Coop, Coop Pronto, Coop bau+hobby, Coop City, Coop@ } \\
\text { home, Interdiscount, TopTip, Impo, Christ }\end{array}$ \\
\cline { 2 - 3 } & Migros & $\begin{array}{l}\text { M, MM, MMM, Migros Restaurant, m-electronics Globus } \\
\text { (department stores), OBI (franchise), Office World, interio }\end{array}$ \\
\hline brand & Metro & Metro Cash\&Carry, Real, Media-Markt, Saturn, Kufhof \\
\cline { 2 - 3 } & Kingfisher & B\&Q, Castorama, Brico Depot, Screwfix, Koctas \\
\cline { 2 - 3 } & Casino & Geant, Casino, Leader Price, Monoprix \\
\cline { 2 - 3 } & Carrefour & Carrefour, Dia, Champion, Ed, Minipreco, Ooshop.com \\
\cline { 2 - 3 } & DSG International & Currys, Dixon, Dixon.co.uk, PC City, Electro World, Elkjop \\
\hline
\end{tabular}

Source: Levy, M., Weitz, B.A. (2009). Retailing Management.

McGraw-Hill, Irwin, pp. 387. 
There are numerous reasons why a trading company decides to introduce its own product brand (Dunne, Lusch \& Carver, 2014, p. 435):

- To increase sales volume (for example, in the USA and Canada, sales of products with a trademark makes $20 \%$ of the total sales volume),

- To lower prices, increase inventory turnover ratio, and increase profits,

- To gain recognition from consumers (for example, in the USA, $80 \%$ of the products with the trademark is recognizable among consumers),

- To increase the share of brand products in the total company profit,

- To protect from aggressive competition,

- To increase the reputation of the company,

- To increase the negotiating power in relation to manufacturers,

- To gain consumer loyalty to brands, which directly affects the loyalty of consumers to the trade, and so on.

Although literature often interprets trademark as a "form of derivation", i.e. development of a brand, there is no doubt that trademark is the basis for the success of a particular trading company (Ailawadi \& Keller 2004). Consideration of trademarks in the function of the success of a trading company in itself raises a number of issues. First of all, it is necessary to accurately determine the consumers who have affinity with the trademark. Theory and practice have shown that these are consumers who are sensitive to prices, with middle income, and secondary education (Ailawadi, Neslin \& Gedenk, 2001). Consumers with middle income tend to purchase products with the trademark in order to save money.

The question that needs to be considered in respect of trademark is whether it provides greater advantages compared to the manufacturer brand. Several analytical models gave a positive answer to this question, particularly pointing to the fact that a range of products in which trademarks have a high share achieve a high level of price differences (Narasimhan \& Wilcox, 1998).

The third important issue that needs to be considered in conjunction with the trademark refers to product characteristics that contribute to the success of the trademark. Theory and practice have shown that the quality of products that the consumer perceives is of utmost importance for the success of the trademark (Sprott \& Shimp, 2004). The importance of perceived quality stems from the fact that the quality of product with the trademark is an important determinant of the rate of purchase, i.e. that there is a positive relationship between quality and market share of the trademark. Therefore, it is necessary to find the most effective way to improve the perceived quality of the product with the trademark. One of the alternatives is related to increased advertising costs, so that consumers can better notice the trademark.

Historically speaking, trademarks used to be products of poorer quality, which were cheaper alternative to famous manufacturer brands. Over time, retailers, in collaboration with manufacturers, increased the quality of products, without causing the price increase. Today, the prices of products with the trademark are, on average, up to $15 \%$ lower than the products of famous manufacturers, but, despite the lower price, the difference in price realized by retailers is higher than the one realized by manufacturers. The reasons are manifold, but the most important are: avoiding marketing costs of manufacturers and signing long-term contracts with manufacturers, thus securing placement, while retailers, 
on that basis, achieve lower product prices. A special advantage of the introduction of products under the trademark for retailers is ensuring the desired level of product quality. In today's conditions, trading companies mostly insist on generally accepted quality standards, and, thus, on full satisfaction of consumer demands (Ćuzović \& Sokolov Mladenović, 2013).

The highest revenues from products under the trademark in 2012 were achieved by "Wal-Mart". With operations in 28 countries, the generated revenue on this basis amounted to 88.8 billion dollars, which is about $19 \%$ of the total revenue of this company in 2012. In the second and the third place, there are also American companies, "Costco", with revenues of 23.2 billion dollars, and "Caremark" (retailer in the pharmaceutical industry), with revenues of 21.4 billion dollars (http:/www.privatelabelbuyer.com/ articles/87669-top-35-private-label-retailers, accessed on 30.05.2015.).

Trademarks originated in the United States in the 1960s, where they still are of great importance. In 2013, the market value of the products under the private trademark was estimated at 112 billion dollars, which is about $18 \%$ of the total turnover (http:// www.nielsen.com/us/en/newswire/2014/how-10-retailers-are-pushing-private-labelspotential.html, accessed on 30.09.2015.). The market share of these products is growing from year to year. Chart 1 shows the importance of products under the private trademark in some countries.

\section{Chart 1. The market share of products under the trademark in the selected countries in 2013}

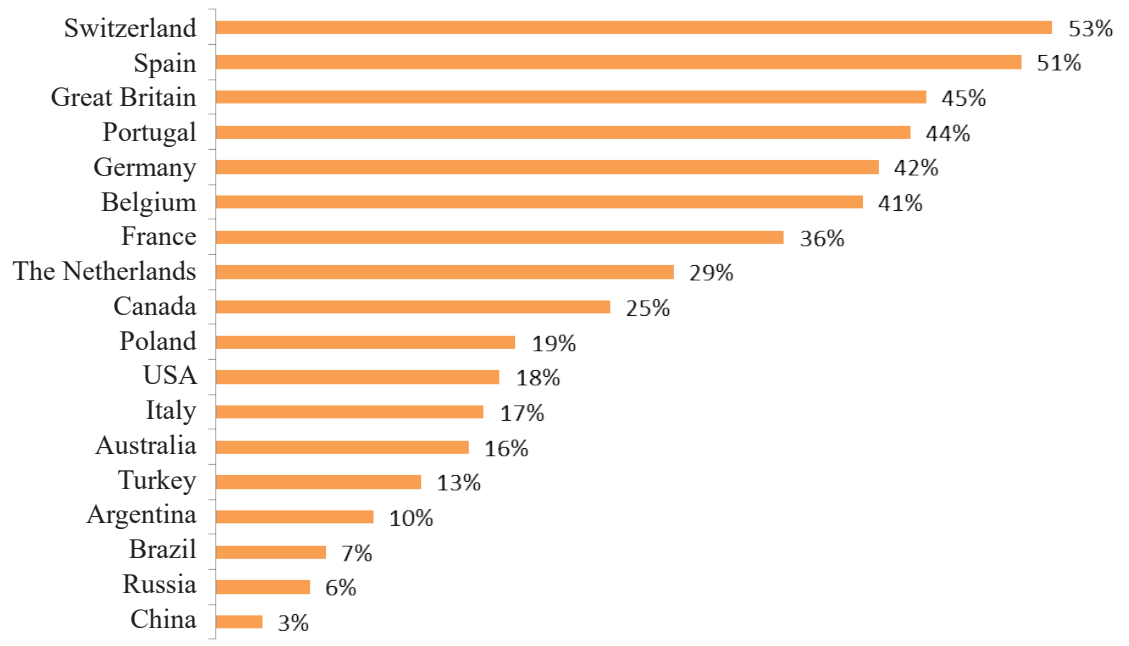

Source: http://www.statista.com/statistics/244903/market-share-of-private-label-brandsworldwide-by-selected-country/ (30.09.2015.)

The first trademark on the Serbian market appeared in 2002, introduced by "C Market". These were the brands under the names "HlebaC" (bread) and "ČistunaC" (cleaning agent). These products had a negligible share in the total turnover. The number of products sold under the trademark has risen since 2005, and is directly linked with 
the expansion of "Delta Maxi" and the advent of regional retail chains, primarily "SuperVero", "Metro", "Mercator", "Interex", "Idea", and "DM". Under the influence of foreign retailers, domestic retail chains, such as "Delta Maxi", "Univerexport", "DIS", and "Lilly" started the intense development of the concept of trademarks (Petljak, Štulec \& Renko, 2011). Currently it is estimated that the market share of products under the trademark in Serbia is about $6 \%$.

\section{Creation and functions of trademarks}

Intense competition on the domestic and foreign market has a stimulating effect on trading companies to include products with their own trademark or brand in the structure of their range of products. This business orientation means creating a brand that has the following characteristics (Alexander \& Doherty, 2009, p. 210): different in comparison to the competition, reflects the image of quality at a low price, exists independently of the company, provides significant value for consumers.

Any creation of a successful brand by the trading company implies respect for the principles of diversity of products compared to the competition. In that sense, the companies that are characterized by brand orientation must observe their entire organization as an entity that is focused on creating brand. This is illustrated by Bridson and Evans's (2004) opinion, who see brand orientation, in the context of trade, as a multidimensional synthesis which includes organizational values, beliefs, behavior, and practices (p. 403). Consequently, brand creation requires features such as diversity, functionality, quality of added value and symbolic value for consumers.

Each orientation to brand increases the performance of the company, as a result of the four key advantages (Bridson \& Evans, 2004, p. 404):

1. The advantage of the range of products - the construction of different brand of products in relation to the competition;

2. The advantage of services to consumers - additional level of service in stores;

3. The advantage of communication - promoting functional characteristics of branded products;

4. The advantage of business formats - reflecting brand personality.

These elements point to the integration of brands and environment in which trading companies operate. In addition, they emphasize the importance of value for customers and different brand personality, which is important for differentiation of trading companies operating on various foreign markets.

However, when building a brand, it is important that trading companies pass through certain levels, or phases, which will allow them to successfully position themselves on the market. This view is confirmed in the research carried out by the theorist Burt, implying that the trading company passes through six levels in the development of trademark, i.e. brand, as can be seen in Overview 2. 
Overview 2. Levels of brand development in trading companies

\author{
Level 1: Non-branded products \\ Character: Products for the satisfaction of basic needs \\ Context: Demand exceeds supply \\ Consumers: Basic knowledge about the usefulness of the product
}

Level 2: Brand as a reference

Character: Physical attributes differentiate the product

Context: Competitive pressures stimulate differentiation

Consumers: Products are identified on the basis of differentiation

Level 3: Brand as a personality

Character: Brand personality provides differentiation

Context: Delivery of products with similar physical attributes

Consumers: Brand knowledge leads to self-expression

Level 4: Brand as an icon

Character: Networking reflects importance and identity

Context: Brand educates the consumer society

Consumers: Consumers accept the brand to create identity

Level 5: Brand as a company

Character: Complexity of identity generates multifunctional communication between stakeholders and the company

Context: Sophisticated brand

Consumers: Consumers are interactively involved in creating brand

Level 6: Brand as a policy

Character: Brand regulated by different causes

Context: Heterogeneity of social value system

Consumers: Self-actualization through brand affinity

Source: Burt, S. (2000). The Strategic Role of Retail Brands in British

Grocery Retailing. European Journal of Marketing, 34 (8), 87.

Passing through the previously presented levels of brand develop ment leads to corporate branding, which is especially important in the process of internationalization of trade. This importance stems from the fact that corporate branding is not just company branding, but broader reflection of the company relations with diverse groups of stakeholders. Through corporate branding, trading company is able to better differentiate and position itself in the "thoughts" of stakeholders, enabling it to build value that is easily identifiable.

Balmer and Greyser (2006) link corporate branding of trading companies to six “C”s (character, culture, communications, conceptualization, constituencies, covenants) (p. 730):

- Character - points to the factors that create a distinct entity. These can be tangible and intangible assets of the company, or the company's activities, its market, corporate assets, corporate structure, type of organization, corporate philosophy, and corporate history; 
- Culture - points to a set of beliefs, values, and assumptions of employees, derived from the history and heritage of the company;

- Communications - points to various forms of communication with consumers and other stakeholders;

- Conceptualization - points to the corporate brand perception by consumers and key stakeholders. These perceptions can be latent and influence the behavior and views of the company;

- Constituencies - point to different groups of stakeholders, such as employees, investors, and local communities, enabling the company to operate on different markets;

- Covenants - point to company's informal contracts with customers and other stakeholders, who have a loyalty to and belief in corporate brand. Contrary to the visible property that makes the entity of the company, these agreements indicate emotional assets that reflect a strong bond of stakeholders with the brand.

So, corporate branding is not just the branding of the company and products that make up the structure of the range. Based on the above facts, it can be concluded that the trading companies in the process of internationalization of business tend to be well positioned on the chosen market, through the construction of the structure of the corporate brand.

\section{Partnership of trade with manufacturers - key to successful trademark}

Through the introduction of a trademark, trading company seeks to differentiate itself against the competition and become recognizable among consumers. The image the products with trademark acquire positively reflects on the image of stores and even the entire trading company. In addition to these, there are numerous other advantages of the product with the trademark, which has already been discussed.

When it comes to products with the trademark, it should be noted that these are products that are manufactured by or based on the order of some trading company, which are sold under its name or trademark through its own sales outlets.

Products with the trademark or trade brand do not provide benefits only to trade, but also to manufacturers. Through these products, manufacturers are in a situation that allows them to reduce the risks of market failures, or strategic risk, given that trade is responsible for the placement of products with trademark and, possibly, the failure of such products. Then, the manufacturers take advantage of capacities and lower cost per unit of production as a result of economies of scale. Specifically, manufacturers can, based on the orders of the trade, produce a certain volume of products, and produce one part of the products under their own brand, which is reflected in the increase of production volumes, higher capacity utilization, and lowering costs per unit of product.

Business with trademark allows manufacturers to avoid high costs of introducing a new product on the market, considering that the trade is now responsible for the introduction of new products. Finally, manufacturers have the opportunity to market their 
own brand along with the products with trademark, so that an image that a trademark has affects the building and improving the image of manufacturer brand.

The above advantages of doing business with the trademark, from the aspect of trade and manufacturers, increase the interest for cooperation between trade and manufacturers, in order to create successful trademarks.

One example of partnership between trade and manufacturers in the development of trademarks is METRO Cash \& Carry, which operates within the METRO Group. METRO Cash \& Carry is present in 29 countries worldwide, with more than 700 distribution centers and more than 120,000 employees. In 2012, the company generated sales of around 32 billion euros. It offers a wide range of products, designed for customers in the field of catering, trade, and craft.

METRO Cash \& Carry Serbia started its operations in 2005 in Belgrade, and today has 7 distribution centers in Belgrade, Kragujevac, Niš, Novi Sad, Subotica, Šabac, Užice, and Požarevac. METRO Cash \& Carry Serbia wants to provide a consistent development strategy and sustainable profitable growth through a unified approach as a responsible partner, primarily as an employer, then in business, social, economic, and cultural role of a reliable regional partner. METRO Cash \& Carry started with the production of products under the trademark in 2006, and today has even 1,100 products in the range of trademarks that are manufactured in Serbia. What is probably the most important result in recent years is the fact that Serbian products are currently exported and sold in Austria, Croatia, Hungary, Romania, Czech Republic, Slovakia, Ukraine, and Moldova. It exports almost all types of products: preserves, canned vegetables, sweets, creams, snacks, hygiene products, and textile products. To Metro Moldova, for example, 16 producers export 206 items produced in Serbia. The greatest interest in the METRO network of distribution centers exists for Serbian items in the area of food, household chemicals, and textiles, produced under the trademarks METRO Cash \& Carry, which guarantee to buyers in other countries the quality and durability of these products.

METRO Cash \& Carry increased the number of manufacturers from Serbia who are involved in the program of trademarks, and it is also planned to increase the volume and number of local products that will be found in their stores across Europe. Through the system METRO Cash \& Carry, manufacturers from Serbia have placed their products in eight European countries, six of which are the members of the European Union. The program of METRO Cash \& Carry trademarks includes 155 manufacturers from Serbia, 96 in the food sector, 26 in the area of household chemicals, and 33 in the non - food sector.

METRO Cash \& Carry trademark has brought a number of advantages to manufacturers participating in the partnership, such as: secured production of pre-agreed amount of goods, significant reduction of the costs of production and transportation, eliminating investment in marketing, market research, presentation, distribution, and sales promotion.

However, in order for the manufacturer to start producing products for METRO, it is necessary to test products, which must meet quality and capacity of production and be sufficient to constantly cover the necessary amount of goods. Quality control inspects the manufacturing plant unannounced several times a year. Metro Cash \& Carry develops trademarks in cooperation with its professional customers in the commercial, catering, and office sectors, and thus adapts them to their specific needs. As a result of 
partnerships with manufacturers, METRO Cash \& Carry offers six exclusive trademarks on the Serbian market: Fine food, Horeca Select, Rioba, Aro, H-line, Sigma. They are developed in cooperation with customers, who have expressed their specific wishes regarding the quality, characteristics, packaging, and price (http://www.metro.rs/public/ naslovna/asortiman/robne-marke, 6.10.2015.).

\section{Conclusion}

The partnership between manufacturers and trade has become imperative in modern business conditions. The stage of conflict between the two sides has shifted to the stage of partnership relations in different business segments. One of them, which has in recent years gained importance in many economies, is the segment of the trademark. The paper specifically analyzed different forms of partnership between trade and manufacturers. The subject of specific analysis was the trademark, its forms, creation, and functions. The fact that partnership between trade and manufacturers is the key to successful trademark is especially emphasized in the paper. The work pointed out numerous examples of trademark development by the leading trading companies. The theoretical part of the paper pointed to the advantages of trademarks for manufacturers and trade, which confirmed the starting hypothesis. Further confirmation of the starting hypothesis lies in the analysis of the case study of the trading company METRO Cash \& Carry Serbia, which, in the field of trademarks, develops partnerships on the Serbian market with 155 manufacturers, which brings numerous benefits to both sides.

\section{References}

Ailawadi, K.L., Keller, K.L. (2004). Understanding retail branding: conceptual insights and research priorities. Journal of Retailing, 80 (4), 330-340.

Ailawadi, K.L., Neslin, S.A., Gedenk, K. (2001). Pursuing the value-conscious consumer: store brands versus national brand promotions. Journal of Marketing, 65(1), 69-75.

Alexander, N., Doherty, A.M. (2009). International Retailing. New York, Oxford University Press.

Balmer, J., Greyser, S. (2006). Corporate Marketing. European Journal of Marketing, 40 (7-8), 730-740.

Bridson, K., Evans, J. (2004). The Secret to a Fashion Advantage is Brand Orientation. International Journal of Retail and Distribution Management, 32 (8), 401-410.

Burt, S. (2000). The Strategic Role of Retail Brands in British Grocery Retailing. European Journal of Marketing, 34 (8), 870-878.

Ćuzović, S., Sokolov Mladenović, S. (2013). Estetizacija sistema kvaliteta u funkciji korporativne prepoznatljivosti trgovinskog preduzeća. Anali Ekonomskog fakulteta u Subotici, 49 (4), 279-293. 
Ćuzović, S., Sokolov Mladenović, S. (2013). Važnost partnerstva trgovine i proizvođača u opskrbnom lancu za osiguranje kvalitete asortimana proizvoda. Međunarodna konferencija Perspektive trgovine 2013: Odnosi u lancima opskrbe, Zagreb, str. 134-152.

Diamond, J., Litt, S. (2010). Retailing in the Twenty-First Century. New York, Fairchild Books.

Dunne, P.M., Lusch, R.F., Carver, J.R. (2014). Retailing. Canada, South-Western Cengage Learning.

http://www.metro.rs/public/naslovna/asortiman/robne-marke (6.10.2015.)

http://www.nielsen.com/us/en/newswire/2014/how-10-retailers-are-pushing-privatelabels-potential.html (30.09.2015.)

http://www.privatelabelbuyer.com/articles/87669-top-35-private-label-retailers (30.05.2015.)

http://www.statista.com/statistics/244903/market-share-of-private-label-brandsworldwide-by-selected-country/ (30.09.2015.)

Kotler, F., Keller, K.L., Martinović, M. (2014). Upravljanje marketingom. Zagreb, MATE d.o.o.

Levy, M., Weitz, B.A. (2009). Retailing Management. Irwin, McGraw-Hill.

Meintzer, J.T, Min, S., Zacharia, Z.G. (2000). The Nature of Interfirm Partnering in Supply Chain Management. Journal of Retailing, 76 (4), 112-119.

Mohr, J.J., Spekman, R.E. (1996). Perfecting Partnership. Marketing Management, 4 (4), 31-40.

Narasimhan, C., Wilcox, R. (1998). Private labels and the channel relationship: A cross-category analysis. Journal of Business, 71 (4), 572-580.

Petljak, K., Štulec, I., Renko, S. (2011). Trgovačke marke u zemljama jugoistočne Europe. Međunarodni znanstveni skup Trgovina kao pokretač razvoja srednje i jugoistočne Evrope, Ekonomski fakultet, Zagreb, str. 214-231.

Sprott, D.E., Shimp, T.A. (2004). Using product sampling to augment the perceived quality of store abrand. Journal of Retailing, 80 (4), 301-309.

Zentes, J., Morschett, D., Schramm-Klein, H. (2007). Strategic Retail Management. Wiesbaden, Gabler. 